\title{
A Comparative Analysis of Opinion On Various Bioethical Issues Based On Religiosity: A Pilot Study With Medical Graduates
}

\author{
Princy Louis Palatty ${ }^{1}$, Paul Simon ${ }^{2}$, Dhanya Sacheendran ${ }^{1}$, Mamatha Jayachandran ${ }^{1}$, \\ Nikku Mathew Geevarughese ${ }^{2}$, Thomas George ${ }^{2}$, Manjeshwar ShrinathBaliga ${ }^{3}$ \\ ${ }^{1}$ Department of Pharmacology, Amrita Institute of Medical Sciences, Edappally, Kochi, Kerala, \\ India 682041. \\ ${ }^{2}$ UNESCO Bioethics South India Unit at Father Muller Medical College, Kankanady, Mangalore, \\ Karnataka, India 575002. \\ ${ }^{3}$ Bioethics Education \& Research Unit of the UNESCO Chair in Bioethics, at Mangalore Institute \\ of Oncology, Mangalore, Karnataka, India 575002.
}

Corresponding author: Manjeshwar Shrinath Baliga

Email: msbaliga@gmail.com

\begin{abstract}
Background: Religiosity which by definition means people's varying tendencies to commit themselves to religious beliefs is an important aspect in society and especially in bioethics, a field concerned with the moral, legal, political, and social issues raised by medicine, biomedical research, and life sciences technologies. Globally, studies on the impact of religiosity on aspects that are debatable and engrained with ethical issues have been minimally investigated. The current study attempts at understanding the opinion of medical graduates through a structured questionnaire.

Methodology: A total of 207 graduates' volunteers to be a part of the study and majority $(72.2 \%)$ were females. The most important aspect was that $83.93 \%$ expressed that they followed their religion strongly. The data was stratified based on this and subjected to detail analysis to understand the opinion of the graduated based on their degree of religiosity.

Results: A significant difference for questions related to opinion pertaining on embryonic stem cell research is unethical $(p=0.017)$ and to right to end his or her own life when in terminal condition $(\mathrm{p}=0.033)$.

Conclusion: As far as the authors are aware of this is the first study that addresses the role of religiosity on opinion to some bioethical aspects with medical graduates from India and the results indicate that religiosity does influence medical practice and opinion on embryonic stem cell research and right to end life in terminal condition.
\end{abstract}

Key words: Bioethics, medical graduates, religion, religiosity, end of life issues, embryonic stem cell research.

\section{Introduction}

Religion is the belief and worship of superhuman being /s (commonly termed as God), following a unique culture, while spirituality refers to adhering to a broad set of principles that transcend all religions and being in right relationship and understanding mutual interdependence of all human beings [1]. Religion and spirituality are the two determining factors in defining the values of life 
and is termed as the inner call of the human being to respond to life in the world [2-3]. Religion is a collation of cultural and belief through which the world views humanity and moral values. Many religions have narratives, symbols, traditions and sacred histories that are intended to give meaning to life or to explain the origin of life and the [2-3].

The basic religions in the world are Christianity, Islam, Judaism, Hinduism and Judaism (The big five); the others include Zoroastrianism, Sikhism, Baha'i faith, Shintoism, Taoism, etc [2-3]. The etymology of the word religion itself is a self-explanatory concept (Latin: "religious" - 'to bind together') [2-3]. The followers of a religion mean sharing the same faith, participating in rituals and adhering to the precepts of the community and espousing it when the need arises. Although a religion is considered as "one", at times it has significant diversity in practice among the followers. At times religion also draws others to community and follows a culture rather than the belief itself. Globally, most countries have governments that favour to protect citizens freedom to follow religion of their choice without privileges or penalty. The human rights enshrine this principle and this is considered a 'fundamental freedom'. In lieu of these observations it can be termed as religion is an overwhelming influence in a person's life. The choices an individual makes would inadvertently pursue the tenets of his faith and belief of the followers. Thus, all decisions would invariably be influenced by religion.

On the contrary, ethics concerns recommendation of right attitudes and behaviours is based on adherence to the inherent nature of the attitude and prevailing moral theories. In fact, John Dewey stated that ethics is considered as a function of moral life of the community [4]. Bioethics is a multidimensional discipline that has varied inputs. The ontogenesis of ethics is based on for native values, environment and experiences. Surgery, transfusions, organ grafting etc, are anathemas, in most religions. The alteration of the body is considered, blasphemous by the religious orthodox, even at the cost of their own wellbeing. In the recent past there has been a positive association between religious involvement and better health.

Medicine is the applied science or practice of the diagnosis, treatment, and prevention of disease [5-6]. It encompasses a variety of health care practices evolved to maintain and restore health by the prevention and treatment of illness in human beings. Medicine and religion have been closely associated since time immemorial and the belief that science alone cannot cure a disease is widely prevalent [5-7]. Spirituality and religion are known to be inversely related to science and in most religions, diseases are considered by most as "ire of the gods' or "taboo" to be manipulated [6-10]. Religious beliefs are strongly held in an individual tract, a physician's religious learning could influence practise of medicine [7-9,11]. When education and awareness sheds light upon an action that adversely affects some or many, the thought of changing such practices/decisions is necessitated and the remedial or alternate is adopted. Religious beliefs could affect ethical decision making and influence personal choice in health care advancements.

Healthcare professionals have to practise their art within the inhibitory and vacillator spectrum of religious beliefs. The health providers need to be attuned to this fact. Doctors with their own individual religious beliefs and the teachings of medical science are at crossroads. The impact of the doctor's own spirituality and religious attitudes could swerve the practise of medicine. The attitudinal development of a doctor occurs at home in social and educational environment. A study to ascertain the attitudes of the undergraduate and post graduate medical students would give inkling into the practise of medicine and religiousness. Considering this the present study was conducted to ascertain the differences in perspectives of undergraduate and postgraduate medical students on their concepts of religion and whether this impacts their attitudes towards bioethical issues.

\section{Materials and Methods}

This study is a single centre study and was conducted under the aegis of the UNESCO Bioethics South India Unit at Father Muller Medical College, Mangalore, India after obtaining the permission of the Institutional Ethics committee. The questionnaire was designed by the investigators and was developed by a local panel of experts in bioethics and researchers. Special attention was given for clarity and the inclusion of the full range of response options. The questionnaire was then pilot tested with 10 students, who were not part of the final sample. The 
respondents of the pilot cohort rated the initial questionnaire for clarity and content validity. Emphasis was placed on the opinion for the comprehension and understanding of the meaning of each question. The final instrument underwent only minor grammatical changes and consisted of five demographic questions and twenty subject specific questions.

\section{Study Population and Survey Methods}

The study population consisted of MBBS graduates who had registered for postgraduate entrance exam training centres in Mangalore and was carried out in December 2016. The investigators approached the medical graduates individually and briefed about the study purpose. As some questions were dilemmatic the volunteers were also requested not write their names or leave any identification mark on the study questionnaire and requested to return back the filled sheets. Written consent was obtained on separate sheet from all the participants before the administration of the questionnaire.

\section{Statistical analysis}

Data was entered in Microsoft excel and answers on the questions were subjected to a quantitative analysis using the Chi-square test and Fisher's exact test using the SPSS software program version 17 from IBM. A $p$ value of $<0.05$ was considered significant.

\section{Results}

A total of 225 questionnaires were distributed but only 207 responded. The results of the study are presented in Table 1 and Table 2. With regard to gender, the results suggest that majority $(72.2 \%)$ of the volunteers were female medical graduates (Table 1). With regard to the question on whether students had attended classes in bioethics, $50.99 \%$ of the volunteers agreed while $49.01 \%$ expressed had not attended the classes (Table 1). The other most important observation was that $88.27 \%$ agreed that bioethics has an important role in healthcare curriculum and profession. Majority of the volunteers $(67.98 \%)$ confessed that they did not read books or articles on bioethics (Table 1$)$. The important aspect was that $83.93 \%$ of the volunteers agreed that they followed religion strongly (Table 1).

Table 1: Details of gender, teaching reading and opinion on importance of bioethics and following religion by the medical graduates

\begin{tabular}{|l|c|c|c|}
\hline Questions & Choice & Total & Percentage \\
\hline \multirow{4}{*}{ 1. Gender } & Male & 57 & 27.8 \\
\cline { 2 - 4 } & Female & 148 & 72.2 \\
\cline { 2 - 4 } & Total & 205 & 100 \\
\hline \multirow{2}{*}{$\begin{array}{l}\text { 2. Have you attended any classes on } \\
\text { bioethics? }\end{array}$} & Yes & 103 & 50.99 \\
\cline { 2 - 4 } & No & 99 & 49.01 \\
\cline { 2 - 4 } & Total & 202 & 100 \\
\hline \multirow{2}{*}{$\begin{array}{l}\text { 3. Do you feel bioethics has important } \\
\text { role in healthcare curriculum and } \\
\text { profession? }\end{array}$} & Yes & 173 & 88.27 \\
\cline { 2 - 4 } $\begin{array}{l}\text { 4. Do you read bioethics books or } \\
\text { articles on bioethics? }\end{array}$ & No & 23 & 11.73 \\
\cline { 2 - 4 } & Total & 196 & 100 \\
\hline \multirow{2}{*}{ 5. Do you follow religion strongly? } & Yes & 65 & 32.02 \\
\cline { 2 - 4 } & No & 138 & 67.98 \\
\cline { 2 - 4 } & Total & 203 & 100 \\
\cline { 2 - 4 } & Yes & 141 & 83.93 \\
\cline { 2 - 4 } & No & 27 & 16.07 \\
\hline
\end{tabular}

For the question," do you think embryonic stem cell research is unethical?", the medical graduates who were religious expressed its unethical nature $(p=0.017)$. With respect to the question, "do you feel you should not tamper god's creation in the name of advancement of science?", the students who were religious opined that tampering of god's creation in the name of advancement 
of science, was not acceptable and this was an emerging new trend among the graduates ( $\mathrm{p}=$ 0.063 ). For the question, "I try hard to carry my religious beliefs over into all my dealings in life", the medical graduates who were religious carry their beliefs into all their dealings in life $(p=0.003)$. With regard to the question, "do you feel religious beliefs influence medical professionals" ( $p=$ 0.088). Professionals who were religious opined that their religious beliefs have an influence in the delivery of healthcare (Table 2). To the question "do you think a patient has the right to end his or her own life when in terminal condition", students who were religious expressed that patient did not have the right to end his or her own life when in terminal condition $(p=0.033)$ (Table 2).

Table 2: Opinion expressed by the medical graduates who followed religion strongly as versus to not for the various questions addressing the medical fraternity

\begin{tabular}{|c|c|c|c|}
\hline Questions & Choice & $\begin{array}{l}\text { Religious } \\
\text { N (\%) }\end{array}$ & $\begin{array}{c}\text { Not religious } \\
\text { N (\%) }\end{array}$ \\
\hline \multirow{6}{*}{$\begin{array}{l}\text { 1.Do you think scientific and } \\
\text { medical progress is hindered } \\
\text { by religion? }\end{array}$} & Strongly agree & $18(12.9)$ & $5(18.5)$ \\
\hline & Somewhat agree & $73(52.1)$ & $15(55.6)$ \\
\hline & Somewhat disagree & $22(15.7)$ & $4(14.8)$ \\
\hline & Strongly disagree & $27(19.3)$ & $3(11.1)$ \\
\hline & Chi square & \multicolumn{2}{|l|}{1.431} \\
\hline & P value & \multicolumn{2}{|l|}{0.698} \\
\hline \multirow{6}{*}{$\begin{array}{l}\text { 2.Do you feel religion is over } \\
\text { pressing bioethical issue }\end{array}$} & Strongly agree & $16(11.5)$ & $5(19.2)$ \\
\hline & Somewhat agree & $58(41.7)$ & $15(57.7)$ \\
\hline & Somewhat disagree & $42(30.2)$ & $3(11.5)$ \\
\hline & Strongly disagree & $23(16.5)$ & $3(11.5)$ \\
\hline & Chi square & \multicolumn{2}{|l|}{1.248} \\
\hline & P value & \multicolumn{2}{|l|}{0.741} \\
\hline \multirow{6}{*}{$\begin{array}{l}\text { 3.Do you feel science must } \\
\text { advance at the cost of animal } \\
\text { and human experimentation? }\end{array}$} & Strongly agree & $21(15.3)$ & $6(24.0)$ \\
\hline & Somewhat agree & $53(38.7)$ & $8(32.0)$ \\
\hline & Somewhat disagree & $36(26.3)$ & $6(24.0)$ \\
\hline & Strongly disagree & $27(19.7)$ & $5(20.0)$ \\
\hline & Chi square & \multicolumn{2}{|l|}{1.248} \\
\hline & P value & \multicolumn{2}{|l|}{0.741} \\
\hline \multirow{6}{*}{$\begin{array}{l}\text { 4.Should religious healthcare } \\
\text { professionals hinder } \\
\text { healthcare services? }\end{array}$} & Strongly agree & $12(9.2)$ & $4(15.4)$ \\
\hline & Somewhat agree & $22(16.9)$ & $3(11.5)$ \\
\hline & Somewhat disagree & $41(31.5)$ & $5(19.2)$ \\
\hline & Strongly disagree & $55(42.3)$ & $14(53.8)$ \\
\hline & Chi square & \multicolumn{2}{|l|}{2.957} \\
\hline & $P$ value & \multicolumn{2}{|l|}{0.398} \\
\hline \multirow{6}{*}{$\begin{array}{l}\text { 5.Do you think genetically } \\
\text { modified food ie brinjal is } \\
\text { harmful? }\end{array}$} & Strongly agree & $17(12.4)$ & $3(12.0)$ \\
\hline & Somewhat agree & $40(29.2)$ & $6(24.0)$ \\
\hline & Somewhat disagree & $41(29.9)$ & $5(200)$ \\
\hline & Strongly disagree & $39(28.5)$ & $11(44.0)$ \\
\hline & Chi square & \multicolumn{2}{|l|}{2.590} \\
\hline & $P$ value & \multicolumn{2}{|l|}{0.459} \\
\hline \multirow{6}{*}{$\begin{array}{l}\text { 6.Do you think genotyping } \\
\text { should be done by all } \\
\text { patients? }\end{array}$} & Strongly agree & $15(11.2)$ & $2(8.3)$ \\
\hline & Somewhat agree & $43(32.1)$ & $8(33.3)$ \\
\hline & Somewhat disagree & $52(38.8)$ & $6(25.0)$ \\
\hline & Strongly disagree & $24(17.9)$ & $8(33.3)$ \\
\hline & Chi square & \multicolumn{2}{|l|}{3.612} \\
\hline & $P$ value & \multicolumn{2}{|l|}{0.307} \\
\hline
\end{tabular}




\begin{tabular}{|c|c|c|c|}
\hline \multirow{6}{*}{$\begin{array}{l}\text { 7.Do you think embryonic } \\
\text { stem cell research is } \\
\text { unethical? }\end{array}$} & Strongly agree & $14(10.3)$ & $0(0.0)$ \\
\hline & Somewhat agree & $37(27.2)$ & $4(16.7)$ \\
\hline & Somewhat disagree & $56(41.2)$ & $8(33.3)$ \\
\hline & Strongly disagree & $29(21.3)$ & $12(50.0)$ \\
\hline & Chi square & \multicolumn{2}{|l|}{10.215} \\
\hline & $P$ value & \multicolumn{2}{|l|}{0.017 Significant } \\
\hline \multirow{6}{*}{$\begin{array}{l}\text { 8. Do you feel you should } \\
\text { not tamper god's creation in } \\
\text { the name of advancement of } \\
\text { science? }\end{array}$} & Strongly agree & $39(28.7)$ & $6(24.0)$ \\
\hline & Somewhat agree & $52(38.2)$ & $4(16.0)$ \\
\hline & Somewhat disagree & $28(20.6)$ & $9(36.0)$ \\
\hline & Strongly disagree & $17(12.5)$ & $6(24.0)$ \\
\hline & Chi square & \multicolumn{2}{|l|}{7.305} \\
\hline & $P$ value & \multicolumn{2}{|l|}{0.063 Trend } \\
\hline \multirow{6}{*}{$\begin{array}{l}\text { 9.Is the influence of } \\
\text { religion/spirituality on } \\
\text { health generally positive or } \\
\text { negative? }\end{array}$} & Strongly agree & $45(36.9)$ & $4(23.5)$ \\
\hline & Somewhat agree & $58(47.5)$ & $10(58.5)$ \\
\hline & Somewhat disagree & $16(13.1)$ & $3(17.6)$ \\
\hline & Strongly disagree & $3(2.5)$ & $0(0.0)$ \\
\hline & Chi square & \multicolumn{2}{|l|}{1.786} \\
\hline & $P$ value & \multicolumn{2}{|l|}{0.618} \\
\hline \multirow{6}{*}{$\begin{array}{l}\text { 10. Religion/spirituality } \\
\text { helps patients to cope with } \\
\text { and endure illness and } \\
\text { suffering? }\end{array}$} & Strongly agree & $85(61.2)$ & $11(45.8)$ \\
\hline & Somewhat agree & $46(33.1)$ & $10(41.7)$ \\
\hline & Somewhat disagree & $5(3.6)$ & $2(8.3)$ \\
\hline & Strongly disagree & $3(2.2)$ & $1(4.2)$ \\
\hline & Chi square & \multicolumn{2}{|l|}{2.559} \\
\hline & $P$ value & \multicolumn{2}{|l|}{0.447} \\
\hline \multirow{6}{*}{$\begin{array}{l}\text { 11. Religion/spirituality } \\
\text { gives patients a positive } \\
\text { helpful state of mind }\end{array}$} & Strongly agree & $95(68.8)$ & $13(50.0)$ \\
\hline & Somewhat agree & $39(28.3)$ & $11(42.3)$ \\
\hline & Somewhat disagree & $3(2.2)$ & $2(7.7)$ \\
\hline & Strongly disagree & $1(0.7)$ & $2(0.0)$ \\
\hline & Chi square & \multicolumn{2}{|l|}{4.96} \\
\hline & $P$ value & \multicolumn{2}{|l|}{0.416} \\
\hline \multirow{6}{*}{$\begin{array}{l}\text { 12. How often have your } \\
\text { patients received emotional } \\
\text { or practical support from } \\
\text { their }\end{array}$} & Strongly agree & $46(39.0)$ & $7(33.3)$ \\
\hline & Somewhat agree & $61(51.7)$ & $14(66.7)$ \\
\hline & Somewhat disagree & $7(5.9)$ & $0(0.0)$ \\
\hline & Strongly disagree & $4(3.4)$ & $0(0.0)$ \\
\hline & Chi square & \multicolumn{2}{|l|}{2.847} \\
\hline & $P$ value & \multicolumn{2}{|l|}{0.416} \\
\hline \multirow{6}{*}{$\begin{array}{l}\text { 13. Religious/spirituality } \\
\text { causes guilt anxiety or other } \\
\text { negative emotions that lead } \\
\text { to increased patient suffering }\end{array}$} & Strongly agree & $5(3.6)$ & $3(11.5)$ \\
\hline & Somewhat agree & $40(28.6)$ & $9(34.6)$ \\
\hline & Somewhat disagree & $43(30.7)$ & $9(34.6)$ \\
\hline & Strongly disagree & $52(37.1)$ & $5(19.2)$ \\
\hline & Chi square & \multicolumn{2}{|l|}{5.315} \\
\hline & $P$ value & \multicolumn{2}{|l|}{0.150} \\
\hline & Strongly agree & $18(13.1)$ & $2(7.7)$ \\
\hline leads patients to refuse delay & Somewhat agree & $49(35.8)$ & $16(61.5)$ \\
\hline or stop medically indicated & Somewhat disagree & $36(36.3)$ & $3(11.5)$ \\
\hline & Strongly disagree & $34(34.8)$ & $5(19.2)$ \\
\hline & Chi square & 6.437 & \\
\hline & $P$ value & 0.092 & \\
\hline 15. How often have your & Strongly agree & $17(14.2)$ & $3(14.3)$ \\
\hline patients used religious & Somewhat agree & $49(40.8)$ & $7(33.3)$ \\
\hline /spirituality as a reason to & Somewhat disagree & $29(24.2)$ & $6(28.6)$ \\
\hline & Strongly disagree & $25(20.8)$ & $5(23.8)$ \\
\hline
\end{tabular}




\begin{tabular}{|c|c|c|c|}
\hline \multirow{2}{*}{$\begin{array}{l}\text { avoid talking responsibility } \\
\text { for their own health? }\end{array}$} & Chi square & \multicolumn{2}{|l|}{0.467} \\
\hline & $P$ value & \multicolumn{2}{|l|}{0.926} \\
\hline \multirow{6}{*}{$\begin{array}{l}\text { 16. I try hard to carry my } \\
\text { religious beliefs over into all } \\
\text { my dealings in life? }\end{array}$} & Strongly agree & $29(20.9)$ & $2(7.7)$ \\
\hline & Somewhat agree & $70(50.4)$ & $8(30.8)$ \\
\hline & Somewhat disagree & $24(17.3)$ & $6(23.1)$ \\
\hline & Strongly disagree & $16(11.5)$ & $10(38.5)$ \\
\hline & Chi square & \multicolumn{2}{|l|}{14.304} \\
\hline & $P$ value & \multicolumn{2}{|l|}{0.003 Significant } \\
\hline \multirow{6}{*}{$\begin{array}{l}\text { 17. Do you feel religious } \\
\text { beliefs influence medicine? }\end{array}$} & Strongly agree & $36(26.3)$ & $4(16.0)$ \\
\hline & Somewhat agree & $63(4.0)$ & $15(60.0)$ \\
\hline & Somewhat disagree & $25(18.2)$ & $1(4.0)$ \\
\hline & Strongly disagree & $13(9.5)$ & $5(20.0)$ \\
\hline & Chi square & \multicolumn{2}{|l|}{6.543} \\
\hline & $P$ value & \multicolumn{2}{|l|}{0.088 Trend } \\
\hline \multirow{6}{*}{$\begin{array}{l}\text { 18. From ethical point of } \\
\text { view does physician or } \\
\text { someone else have the } \\
\text { responsibility to practice } \\
\text { euthanasia when they are } \\
\text { asked to do so by a } \\
\text { terminally ill patient in a } \\
\text { responsible manner? }\end{array}$} & Strongly agree & $19(14.2)$ & $6(26.1)$ \\
\hline & Somewhat agree & $50(37.3)$ & $9(39.1)$ \\
\hline & Somewhat disagree & $19(14.2)$ & $2(8.7)$ \\
\hline & Strongly disagree & $46(34.3)$ & $6(26.1)$ \\
\hline & Chi square & \multicolumn{2}{|l|}{2.609} \\
\hline & $P$ value & \multicolumn{2}{|l|}{0.456} \\
\hline \multirow{6}{*}{$\begin{array}{l}\text { 19. Should human life be } \\
\text { defended regardless of its } \\
\text { quality? }\end{array}$} & Strongly agree & $36(26.7)$ & $5(20.8)$ \\
\hline & Somewhat agree & $38(28.1)$ & $7(29.2)$ \\
\hline & Somewhat disagree & $35(25.9)$ & $8(33.3)$ \\
\hline & Strongly disagree & $26(19.3)$ & $4(16.7)$ \\
\hline & Chi square & \multicolumn{2}{|l|}{0.762} \\
\hline & $P$ value & \multicolumn{2}{|l|}{0.858} \\
\hline \multirow{6}{*}{$\begin{array}{l}\text { 20. Do you think a patient } \\
\text { has the right to end his or her } \\
\text { own life when in terminal } \\
\text { condition? }\end{array}$} & Strongly agree & $18(12.9)$ & $6(24.0)$ \\
\hline & Somewhat agree & $32(23.0)$ & $10(40.0)$ \\
\hline & Somewhat disagree & $18(12.9)$ & $4(16.0)$ \\
\hline & Strongly disagree & $71(51.1)$ & $5(20.0)$ \\
\hline & Chi square & \multicolumn{2}{|l|}{8.717} \\
\hline & $\mathbf{P}$ value & \multicolumn{2}{|l|}{0.033 significant } \\
\hline
\end{tabular}

\section{Discussion}

Our study investigated the impact of religion on attitudes and practise of medicine. It has been known that religion influences the outpouring of attitudes, decision and values. Being a person of science and following a particular religion could be at times contradictory, invoking a turmoil that gets balanced by rationality. As seen in the study the medical students $83.93 \%$ of the volunteers were religious. In a study conducted Curlin et al, male physicians and those who are religious will be most likely to express personal objections and least likely to disclose information about the interventions or to refer patients to more accommodating providers [12].

Religion has an important role when it comes to decision taking. Underlying religious beliefs and affiliations strongly affects end of life decision taking [13]. They tend to derive morality, ethics, religious laws or a preferred lifestyle from their ideas about the cosmos and human nature. Religion has a substantial impact on patient care [14]. Patient's recovery and well-being are dependent on their beliefs, spiritual needs and support. Incorporation of spiritual and religious dimension as a part of patient care can help patients cope with their illness [14]. While serving the patients; spirituality can help clinicians to reconnect with their professional roots [15]. Maintenance of hope and stability can be provided by the intervention of spirituality [16]. Greater spirituality is one of the factors for good health among geriatric people [11]. Advanced cancer patients, oncologists and 
oncologist nurses value spiritual care [17]. Spiritual development along with professional development is becoming a need as it helps the healthcare individuals to deal with their stress of care giving [15]. Integrating of spiritual needs is also essential along with advanced medical treatment [16]. Making patients understand and coping with medial illness can be achieved by religion [18]. Moral deliberation is substantiated by religious traditions [19].

Limited research data is available on the frequency of spirituality and religion affecting health care professionals [20]. Ethics and informed consent are intertwined which is a central issue on which hangs most of the ethical problems in human experimentation and the options in clinical care [21]. The understanding of interplay of religion and spirituality in health and medicine has increased. There is a renewed interest for its implication on ethicality. Healthcare professionals must acknowledge and address religious issues with regard to disease and health of their patients. In associating with religious issues and needs of the patients the religious and spiritual foundation of the healthcare professional should be sound) [22]. In the study it was observed that $83.93 \%$ of the volunteers were religious. Intrinsic religiosity stands for the extent to which a person embraces his or her religion as the "master motive" that guides and gives meaning to his or her life [12].

The incongruity among the various beliefs arises from vague and incorrectly perceived philosophical concepts. Thoughts about the necessity and moral implications of embryonic stem cell research are governed by a variety of religious, ethical and political factors. Some ethicists strive to ascertain what of who is a person by "setting boundaries" [23]. Supporters of embryonic stem cell research assert that to qualify as a person, the individual must fulfil several criteria to be qualified for personhood such as self-awareness, capacity, curiosity, sense of time and neo-cortical function [24-25]. Those defending this theory, argue that human embryo lacks these criteria and therefore cannot be deemed to have a moral status. Scientists affirm that any harm done is outweighed by the potential alleviation of the suffering endured by tremendous number of people with varying diseases [26-27]. As per the deontological approach, "whether a situation is good or bad depends on whether the action that brought it about was right or wrong", and hence the ends do not justify the means. Therefore, this flimsy utilitarian approach deems that stem cell research proceeds at the expense of human life than at the expense of personhood. This argument fails to address the ethical concerns pertaining to the destruction of embryonic life for the possibility of developing certain treatments to eradicate certain diseases $[25,28]$.

Most religions strongly condemn reproductive cloning because of the belief that life is considered to be a gift from god [29]. Religious leaders rarely show the determination to voice their thoughts or take a stand in this matter. The Roman Catholics oppose human cloning and embryonic stem cell lines because it goes against their belief and faith and it is contradictory to the law of god [29]. Hinduism rejects the use of embryonic stem cells and concurs with Christianity [30-31]. Stem cell research propels possible futuristic notions like eternal life and existence beyond human realms, development of ready to use organs which can potentially alter the dynamics of the whole human race [24]. Islam regards research on stem cells as an act of faith and the ultimate will of God and that the intervention can be undertaken with the sole intent for the greater good and improvement of humanity [32-34]. However, Islam expresses concerns with the reproductive cloning procedures and their potential impact on familial and interpersonal relationships [32-33].

The ethicality of stem cell research was agreed by the nonreligious (83\%) and the religious $(62.5 \%)$. Ethical sensitivity and competence is necessary for excellent clinical care and both religion and spirituality aids in development of ethical sensitivity. However, the relationship between science and religion has been complicated. Science has time and again shaken the very foundations of religious beliefs especially the western nations and if it keeps festering, the religious sentiments and hostility can mount leading to stunting of advancements in science [35].

As medical graduates realised the need for creating a universal form of decision without the overwhelming influences of religion to be professional. Volunteers in this study had training to be professional, that belies religious tug-of-war. In a study conducted in 1988 by Cassidy no significant differences were found on perceptions of idealistic and realistic moral behaviours. Comparison based on age of students and their participation in ethics course and seminars was analysed and significant findings were evident. Exposure to bureaucratic environment of 
healthcare system and participation in educational offerings have attributed to differences in attitudes [36].

Humanistic desire to end suffering and pain has been sheared from religion and spirituality that could influence decision making amongst doctors [37]. Patients and physicians have an element of disagreement of what a "good death" entails [38]. Every human being has the right to determine what shall be done to his own body. Hence informed consent is the ultimate protection from hazards of research and therapy in medicine. The end result should be a rational decision by the patient based on the information provided to him by the researchers or investigators and patient should have full prognosis [21]. Respect to the individual is inherent to religious beliefs and as manifest as autonomy of the patient [21].

In the conceptual framework of relationship amongst human beings, nature and god, religion, spirituality and medicine have common roots [22]. Recent debates have sparked the need for accessibility to legal treatments when the concerned physicians have trouble about the moral implications of the treatment. Certain countries have formulated laws that shield health providers from refusing medical practises that would violate their consciences [12]. Studies have shown that family physicians beliefs and religious practises are similar to the cross section of the population he practises in [39]. Among the healthcare professionals psychiatrist were found to be less religious than their counter parts and their patients [40]. Moreover, healthcare professionals are the crucial link in augmenting bioethical values in the course of their duty. A study by Bapat et al, in South India, that analysed the awareness, attitudes and beliefs of 123 medical students showed $95 \%$ did not believe that organ donation is against religion [41]. The question of religion thus lays a crucial role as it is the belief that prompts the action of the healthcare professional.

Among the ones who follow religion strongly (35.9\%) and 64\% of the ones who do not follow religion strongly agreed that patient has the right to end his or her own life when terminally ill. Physicians are ultimately the decision makers despite having patient directed modes of end of life care [12]. Patient autonomy and end of life decisions are two factors which lead to a dilemma among the health care individuals as well as the patient party. Views on euthanasia are strongly influenced by religion on health care profession[42].The interesting conclusions drawn by Billow $\mathrm{HH}, 2012$ study, was that the religious were more in favour of treatment and more in favour of life prolongation and less likely to administer active euthanasia than the others. The issue of patient autonomy did not show difference between religious and non-religious [42]. Relief from unbearable pain and suffering, euthanasia was supported majority of the doctors [43]. The factors determining, choice of euthanasia among doctors showed that disappointment was seen in those religious and spiritual [44].This study done earlier on doctors and our study done on medical students showed parallel ideology

Religious and non-religious Medical professionals are in agreement that religion casts a positive influence on health. In fact, Ghadirian has indicated relevance of spirituality in the practise of medicine. In fact there is danger of dehumanisation of medical institutions. Consequently growing number of medical education programs implement integration of spirituality and medicine [45]. Impact of religion on health is primarily a positive one. Thus Religion has an important impact on health [46]. Surprisingly, religion helps to cope in illness was agreed to by the religious (94\%) and the non-religious (88\%). Within medicine there is an increased focus on the relation between faith and health [46]. It has been shown in a study by Powell LH et al 2003, that religion and spirituality protects against cardiovascular diseases mediated by lifestyle. The depth of religiousness bears on physical health. Religion and spirituality slows progression of cancer or improves recovery from acute illness. The heavy impact of religion and spirituality on patients, disease course could also affect the treating team. Hence the hypothesis was developed [47]. Religion helps to cope with diseases and its consequences which could conflict with physician's recommendations and the patient could face a conflict with physician's recommendation but navigating this issue is an ethical dilemma [48].

Irrespective of religiousness and qualification all agree that religion provides positive attitude and hopeful state of mind of the patients. Highlighting the importance of religion and spirituality among terminally ill patients would mean the meting out of religion and spirituality by health care professionals [49]. Influence due to religious beliefs in practise of medicine was agreed upon by 
$71.3 \%$ of the participants. As physicians are de facto arbiters, especially, in critical situations, despite having appointed surrogates, their decisions would definitely be influenced by personal religious beliefs [38].

Various studies note the influence of religion on the physicians practise but over simplified religious measures limit the veracity of these studies [38]. Ethnicity, geographic region, experience caring for the dying and religious characteristics have an impact on the physician's perspectives on end of life decisions. Frequent exposure to dying patients and the outcome of survival; also have a bearing on physician's attitude on "end of life" issues [38]. The physician's judgements, beliefs, attitudes and obligations could impinge upon their practise [38]. In a study conducted by and coworkers in the United States it was seen that Christian affiliations try to carry their religious beliefs into other dealings in life than Jewish, Hindu and Muslim physicians [39]. Religious leaders themselves are at times inconsistent with their moral standpoint on various ethical issues that prevaricates the stance to be taken by their faithful. Hence further deliberations and discussions are necessary in concluding a debate on new age healthcare advancements. Despite the methodological limitations in this study, the conclusions drawn are contemplative and gives direction to fostering ethical competence amongst healthcare professionals. A true professional unfetters religiosity and other personal biases in ethical decision making.

\section{REFERENCES}

1. Kaiser LR. Spirituality and the physician executive. Physician Exec 2000;26(2):6-13.

2. Green RM. Religion and medical ethics. Handb Clin Neurol 2013;118:79-89.

3. Güvercin $\mathrm{CH}$, Munir $\mathrm{KM}$. A comparative analysis of bioethical issues from view points of religious affairs administration in Turkey, Roman Catholicism and orthodox Judaism. Acta Bioeth. 2017;23(2):327-39.

4. Miller FG, Fins JJ, Bacchetta MD. Clinical pragmatism: John Dewey and clinical ethics. J Contemp Health Law Policy 1996;13(1):27-51.

5. Liebman JL. Medicine and religion. J Am Med Assoc 1947;134(17):1479-81.

6. Balboni MJ, Puchalski CM, Peteet JR. The relationship between medicine, spirituality and religion: three models for integration. J Religion Health 2014; 53(5):1586-98.

7. Singh DK, Ajinkya S. Spirituality and religion in modern medicine. Indian J Psychol Med 2012; 34(4):399-402.

8. Waldfogel S. Spirituality in Medicine. Prim Care 1997;24:963-76.

9. Broeckaert B. Spirituality and Palliative Care. Indian J Palliat Care 2011;17(Suppl):S39-41.

10. Sulmasy DP. Spirituality, religion, and clinical care. Chest 2009;135(6):1634-1642.

11. Daaleman TP, Perera S, Studenski SA. Religion, spirituality, and health status in geriatric outpatients. Ann Fam Med 2004;2(1):49-53.

12. Curlin FA, Lawrence RE, Chin MH, Lantos JD.. Religion, Conscience, and Controversial Clinical Practises. N Engl J Med 2007;356(6):593-600.

13. Cohen J, van Delden J, Mortier F, Löfmark R, Norup M, Cartwright C, Faisst K, Canova C, Onwuteaka-Philipsen B, Bilsen J; Eureld Consortium. Influence of physicians' life stances on attitudes to end-of-life decisions and actual end-of-life decision-making in six countries. J Med Ethics 2008;34(4):247-53.

14. D'Souza R. The importance of spirituality in medicine and its application to clinical practice. Med J Aust. 2007;186(10 Suppl):S57-9.

15. Puchalski CM. The role of spirituality in health care. Proc (Bayl Univ Med Cent) 2001;14(4):3527.

16. Mattison $\mathrm{D}$. The forgotten spirit: integration of spirituality in health care. Nephrol News Issues 2006;20(2):30-2.

17. Phelps AC, Lauderdale KE, Alcorn S, Dillinger J, Balboni MT, Van Wert M, Vanderweele TJ, Balboni TA. Addressing spirituality within the care of patients at the end of life: perspectives of patients with advanced cancer, oncologists, and oncology nurses. J Clin Oncol 2012;30(20):253844.

18. Koenig, Harold G. Religion, Spirituality, and Medicine: Research Findings and Implications for Clinical Practice. Int J Psychiatry Med 2001;31(3):321-36.

19. Turner L. Bioethics and religions: religious traditions and understandings of morality, health, and illness. Health Care Anal 2003;11(3):181-97. 
20. Hui D, de la Cruz M, Thorney S, Parsons HA, Delgado-Guay M, Bruera E. advanced cancer admitted to an acute palliative care unit. Am J Hosp Palliat Care 2011;28(4):26470 .

21. Barkes P. Bioethics and informed consent in American health care delivery. J Adv Nurs 1979;4(1):23-38.

22. Chattopadhyay S, Religion, spirituality, health and medicine: why should Indian physicians care? J Postgrad Med 2007;53(4):262-6.

23. Aravind VK, Krishnaram VD, Thasneem Z. Boundary crossings and violations in clinical settings. Indian J Psychol Med 2012;34(1):21-4.

24. Leventhal A, Chen G, Negro A, Boehm M. The benefits and risks of stem cell technology. Oral Dis 2012;18(3):217-22.

25. Manzar N, Manzar B, Hussain N, Hussain MF, Raza S. The ethical dilemma of embryonic stem cell research. Sci Eng Ethics 2013;19(1):97-106.

26. Olsen ML, Swetz KM, Mueller PS. Ethical decision making with end-of-life care: palliative sedation and withholding or withdrawing life-sustaining treatments. Mayo Clin Proc 2010;85(10):949-54.

27. Crockett MJ, Kurth-Nelson Z, Siegel JZ, Dayan P, Dolan RJ. Harm to others outweighs harm to self in moral decision making [published correction appears in Proc Natl Acad Sci USA 2015;112(4):E381, Proc Natl Acad Sci USA 2014;111(48):17320-5.

28. Lo B, Parham L. Ethical issues in stem cell research. Endocr Rev 2009;30(3):204-13.

29. Copland PS. The Roman Catholic Church and embryonic stem cells. J Med Ethics 2004;30(6):6078.

30. Sivaraman MA, Noor SN. Human Embryonic Stem Cell Research: Ethical Views of Buddhist, Hindu and Catholic Leaders in Malaysia. Sci Eng Ethics 2016;22(2):467-85.

31. Sivaraman MAF. Ethical Guiding Principles of "Do No Harm" and the "Intention to Save Lives" in relation to Human Embryonic Stem Cell Research: Finding Common Ground between Religious Views and Principles of Medical Ethics. Asian Bioeth Rev 2019;11(4):409-35.

32. Bowen, DL. "Contemporary Muslim Ethics of Abortion." In Islamic Ethics of Life, 51-80. University of South Carolina Press, 2003.

33. Katz, MH. "The Problem of Abortion in Classical Sunni Fiqh." In Islamic Ethics of Life, 25-50. University of South Carolina Press, 2003.

34. Al-Aqeel AI. Human cloning, stem cell research. An Islamic perspective. Saudi Med J. 2009; 30(12):1507-14.

35. Frazzetto G. Embryos, cells and God. EMBO Rep 2004;5(6):553-5.

36. Cassidy VR, Oddi LF. Professional autonomy and ethical decision making among graduate and undergraduate nursing majors. J Nurs Educ 1988;27(9):405-10.

37. Levy TB, Azar S, Huberfeld R, Siegel AM, Strous RD. Attitudes towards euthanasia and assisted suicide: a comparison between psychiatrists and other physicians. Bioethics 2013;27(7):402-8.

38. Curlin FA, Nwodim C, Vance JL, Chin MH, Lantos JD. To Die, to Sleep: US Physicians' Religious and Other Objections to Physician-Assisted Suicide, Terminal Sedation, and Withdrawal of Life Support. Am J Hosp Palliat Care 2008;25(2):112-20.

39. Curlin FA, Lantos JD, Roach CJ, Sellergren SA, Chin MH. Religious Characteristics of U.S. Physicians A National Survey. J Gen Intern Med 2005;20(7):629-34.

40. Curlin FA, Lawrence RE, Odell S, Chin MH, Lantos JD, Koenig HG, Meador KG. Religion, Spirituality, and Medicine: Psychiatrists' and other Physicians' Differing Observations, Interpretations, and Clinical approaches. Am J Psychiatry 2007;164(12):1825-31.

41. Bapat, Kedlaya PG, Gokulnath. Organ donation, awareness, attitudes and beliefs among post graduate medical students. Saudi J Kidney Dis Transpl 2010;21(1):174-80.

42. Bulow HH, Sprung CL, Baras M, Carmel S, Svanteeson M, Benbenishty J, Maia PA, Beishuizen A, Cohen S, Nalos D. Are religion and religiosity important to end-of-life decisions and patient autonomy in the ICU? The Ethicattstudy. Intensive Care Med 2012;38(7):1126-33.

43. Kamath, Bhate P, Mathew G, Sashidharan S, Daniel AB.Attitudes Toward Euthanasia Among Doctors in a Tertiary Care Hospital in South India: A Cross Sectional study. Indian J Palliat Care 2011;17(3):197-201.

44. McCormack M, Clifford M, Conroy M. attitudes of UK doctors towards euthanasia and physicianassisted suicide: a systematic literature review. Palliat Med 2012;26(1):23-33.

45. Ghadirian AM. Is spirituality relevant to the practice of medicine? Med Law 2008;27(2):229-39.

46. Curlin FA, Roach CJ, Gorawara-Bhat R, Lantos JD, Chin MH. How Are Religion and Spirituality Related to Health? A Study of Physicians' Perspectives. South Med J 2005;98(8):761-6.

47. Powell LH, Shahabi L, Thoresen CE. Religion and spirituality. Linkages to physical health. Am Psychol 2003;58(1):36-52. 
48. Curlin FA, Roach CJ, Gorawara-Bhat R, Lantos JD, Chin MH. When Patients Choose Faith Over Medicine Physician Perspectives on Religiously Related Conflict in the Medical Encounter. Arch Intern Med 2005;165(1):88-91.

49. Vallurupalli M, Lauderdale K, Balboni MJ, Phelps AC, Block SD, Ng AK, Kachini LA. The role of spirituality and religious coping in the quality of life of patients with advanced cancer receiving palliative radiation therapy. J Support Oncol 2012;10(2):81-7.

Acknowledgements: Authors would like to extend their heartfelt thanks to all the graduate students that participated in the study.

Conflict of interest: Nil

Funding: Nil 